\title{
The effect of drying temperature on bioactive compounds and antioxidant activity of Leccinum scabrum (Bull.) Gray and Hericium erinaceus (Bull.) Pers.
}

\author{
Monika Gąsecka $^{1}\left(\right.$ Marek Siwulski $^{2} \cdot$ Zuzanna Magdziak $^{1} \cdot$ Sylwia Budzyńska $^{1}$ • \\ Kinga Stuper-Szablewska ${ }^{1} \cdot$ Przemysław Niedzielski $^{3} \cdot$ Mirosław Mleczek $^{1}$
}

Revised: 14 August 2019/Accepted: 3 September 2019/Published online: 18 September 2019

(C) The Author(s) 2019

\begin{abstract}
In the study the effect of drying temperature on phenolic and organic acid content, total phenolic content, ergosterol content, antioxidant activity and content of 40 elements in fruiting bodies of Leccinum scabrum and Hericium erinaceus was estimated. The analysis was performed for fresh fruiting bodies and those dried at 20, 40 and $70{ }^{\circ} \mathrm{C}$. Drying resulted in changes in the profile of phenolic and organic acids. Drying generally resulted in losses of the content of total phenolics, ergosterol and antioxidant activity in both species. However, a reduction and an increase of phenolic acids and organic acids were observed. The greatest reduction of the compounds was generally observed at $70{ }^{\circ} \mathrm{C}$. The greatest losses concerned organic acids (some single components and total) (even more than $90 \%$ of some compounds). The inhibition of free radicals decreased in the following order: fresh samples $>$ air-dried samples $>$ samples dried at $40^{\circ} \mathrm{C}>$ samples dried at $70{ }^{\circ} \mathrm{C}$. The drying temperature affected only selected element contents in fruiting bodies.
\end{abstract}

Keywords Phenolic acids - Organic acids - Antioxidant activity $\cdot$ Ergosterol $\cdot$ Metal content $\cdot$ Mushrooms

Electronic supplementary material The online version of this article (https://doi.org/10.1007/s13197-019-04081-1) contains supplementary material, which is available to authorized users.

Monika Gąsecka

monika.gasecka@up.poznan.pl

1 Department of Chemistry, Poznań University of Life Sciences, Poznan, Poland

2 Department of Vegetable Crops, Poznań University of Life Sciences, Poznan, Poland

3 Faculty of Chemistry, Adam Mickiewicz University in Poznań, Poznan, Poland

\section{Introduction}

Leccinum scabrum (Bull.) Gray belonging to the Boletaceae family occurs throughout the northern hemisphere and in Australia and New Zealand. It is a wild growing species forming mycorrhiza with birch. Leccinum scabrum is one of the most commonly consumed wild growing mushrooms. The most delicious are the young fruiting bodies and caps. It is suitable for direct consumption, drying or processing. Mushroom shelf life at room temperature after harvest is limited to a few days (Akram and Kwon 2010; Sommer et al. 2010). That is why after the direct harvesting from the natural environment fruiting bodies of $L$. scabrum are available in trade also as a dried product. The conditions after harvest as well as culinary treatments greatly affect the quality of mushrooms (Lin et al. 2017; Roncero-Ramos et al. 2017; Sudheer et al. 2016). Hericium erinaceus (Bull.) Pers., also called the lion's mane mushroom, is known as a medicinal mushroom used in East Asia which demonstrates health-promoting effects including antioxidant, antibacterial, anti-aging, antitumor and anti-dementia activity and a neuroprotective effect resulting from the presence of more than 80 kinds of bioactive compounds (Friedman 2015; Li et al. 2016; Lu et al. 2014). It is cultivated in many countries in the world.

Fresh fruiting bodies (especially wild growing) are not available all year round, but consumers can choose dried mushrooms instead. Hot-air drying is a relatively cheap, easily controlled and mostly used drying method (Pendre et al. 2012). However the drying can affect content of some bioactive compounds. It is also important for consumers, who are increasingly appreciating mushrooms not only for their taste but also for their nutritional value and healthy properties associated with the presence of biologically active compounds. 
The nutritional and health benefits of mushrooms are connected with polysaccharides, proteins and amino acids (e.g. leucine, lysine, methionine, tryptophan), dietary fibre (mainly in the form of chitin), essential unsaturated fatty acids, as well as macro- and micronutrients and vitamins $\left(\mathrm{B}_{1}, \mathrm{~B}_{2}, \mathrm{~B}_{12}, \mathrm{C}, \mathrm{D}\right.$, niacin, folic acid), phenolics, organic acids, sterols, alkaloids and terpenoids (Anibal et al. 2015; Heleno et al. 2015; Jedidi et al. 2017; Reid et al. 2017; Sułkowska-Ziaja et al. 2012).

Phenolic compounds are a major group of non-nutrient bioactive substances with antioxidant, antibacterial and anti-inflammatory properties which may promote natural defense mechanisms in humans (Chen et al. 2017b; Heleno et al. 2015; Moro et al. 2012; Nowacka et al. 2014; Souilem et al. 2017). Phenolic compounds may modify metabolic and physiological functions of the human organism and exhibit health-promoting effects (Chen et al. 2017b; Moro et al. 2012; Souilem et al. 2017).

Ergosterol (previtamin $\mathrm{D}_{2}$ ) is a sterol contained in cell membranes which has beneficial effect on human health and many physiological functions due to its antibacterial, anti-inflammatory and anticancer properties, the potential to reduce the incidence of cardiovascular disease as well as inhibition of cyclooxygenase (COX) activity (Chen et al. 2017b; Hu et al. 2006; Phillips et al. 2011; Shao et al. 2010; Zhang et al. 2002). Ergosterol under the influence of radiation is converted to vitamin $\mathrm{D}_{2}$ (a form of vitamin $\mathrm{D}$ ), essential for human metabolism and found naturally in fungi and plants (Mattila et al. 2002; Phillips et al. 2011; Villares et al. 2014).

Organic acids may prevent various diseases because of their antioxidant properties (citric, malic and succinic acids), antibacterial properties (oxalic acid) and anti-inflammatory properties (formic acid) (Altmeyer et al. 1994; Baati et al. 2011; Kwak et al. 2016; Valentão et al. 2005). The metabolites also prevent browning of mushrooms, extend the shelf life and are also responsible for the taste and aroma of mushrooms (Barros et al. 2013; Brennan et al. 2000; Valentão et al. 2005).

The antioxidant properties of bioactive molecules play an important role in preventing damage caused by free radicals (e.g. age-related disorders and cancer) (Genkinger et al. 2004; Shukla and Singh 2007).

In the study the effect of drying temperature on the content of phenolic and organic acids and antioxidant activity in two different species of mushroom was estimated. Additionally the influence of drying temperature on the content of 40 elements was also estimated. The newly presented data provide some important nutritional information about the differences in fresh and dried mushrooms' chemical composition.

\section{Materials and methods}

\section{Mushroom samples}

Wild L. scabrum samples were collected from Wielkopolska Region in Poland $\left(52^{\circ} 40^{\prime} \mathrm{N} 17^{\circ} 10^{\prime} \mathrm{E}\right)$ in mid September 2017.

Hericium erinaceus was cultivated on a mixture of beech, birch and oak sawdust (3:1:1 vol) supplemented with wheat bran in the amount $25 \%$, corn flour (1\%), sucrose $(1 \%)$ and $\mathrm{CaSO}_{4}(1 \%)$ in relation to the substrate dry matter. The mixture was watered to the moisture content of $60 \%$, placed in polypropylene bags $(1 \mathrm{~kg})$, closed with a cotton cork and then sterilized $\left(121{ }^{\circ} \mathrm{C}\right.$, $1.5 \mathrm{~h}$ ). After cooling to room temperature the substrate was inoculated with grain mycelium ( $20 \mathrm{~g}$ per bag) and incubated $\left(25 \pm 1{ }^{\circ} \mathrm{C}\right.$ and $80-85 \%$ air humidity).The cotton cork was removed after the substrate became overgrown with mycelium. Then the bags were placed in the cultivation room $\left(16-18{ }^{\circ} \mathrm{C}\right.$ and air humidity $\left.85-90 \%\right)$ and lighted with a fluorescent lamp (day-light) for $12 \mathrm{~h}$ per day (200 lx intensity of irradiation). The fruiting bodies were harvested successively when they reached maturity. The fruiting bodies of both species were divided into 4 analysis groups as follows: fresh fruiting bodies, dried at air temperature $\left(20^{\circ} \mathrm{C}, 48 \mathrm{~h}\right)$, dried at $40{ }^{\circ} \mathrm{C}(12 \mathrm{~h})$ and $70{ }^{\circ} \mathrm{C}(7 \mathrm{~h})$ in an oven.

\section{Extraction}

The extraction of phenolic and organic acids was carried out on fresh and dried samples. The fresh samples of both species were homogenized, while the dried samples were ground to a fine powder. The samples were mixed with $80 \%$ methanol and shaken for $12 \mathrm{~h}$ at room temperature for extraction of phenolic acids. Organic acids were extracted by water in an ultrasound bath at ambient temperature. Then the samples were centrifuged at $3000 \mathrm{rpm}$, evaporated to dryness at $40{ }^{\circ} \mathrm{C}$ with rotary vacuum and stored at $-20{ }^{\circ} \mathrm{C}$ before analyses. For analysis the extracts were redissolved in $1 \mathrm{~mL}$ of deionized water (for organic acids) and in $80 \%$ methanol (phenolics).

\section{Total phenolic content}

The content of total phenolics (TP) was determined using the Folin-Ciocalteu assay according to Singleton and Rossi (1965) with some modification. The mixture of the extract $(100 \mu \mathrm{L})$ and the Folin-Ciocalteu reagent $(1 \mathrm{~mL}$ diluted with distilled $\mathrm{H}_{2} 0 ; 1: 1$, v/v) and $\mathrm{Na}_{2} \mathrm{CO}_{3}(3 \mathrm{~mL}, 20 \%)$ was incubated for $30 \mathrm{~min}$ in darkness at room temperature. Next the absorbance was measured at $765 \mathrm{~nm}$. The results 
were expressed as mg of gallic acid equivalent (GAE) per $\mathrm{g}$ of dry weight (DW).

\section{UPLC analysis of phenolic compounds}

Phenolic acids and organic acids were identified on an ACQUITY UPLC H-Class System and PDA e $\lambda$ Detector (Waters Corporation, Milford, MA, USA). For separation of the compounds an Acquity UPLC $\mathrm{BEH} \mathrm{C}_{18}$ column $(2.1 \mathrm{~mm} \times 150 \mathrm{~mm}, 1.7 \mu \mathrm{m}$, Waters $)$ thermostated at $35{ }^{\circ} \mathrm{C}$ was used. The gradient elution was performed with water and acetonitrile (both containing $0.1 \%$ formic acid, $\mathrm{pH}=2$ ) at a flow rate of $0.4 \mathrm{~mL} / \mathrm{min}$. Compounds were identified by comparing retention time of the analyzed peaks with the retention time of standards or by adding a specific amount of the standard to the analyzed samples and a repeated analysis. Detection was carried out in a Waters Photodiode Array Detector at $\lambda=280 \mathrm{~nm}$ and $\lambda=320 \mathrm{~nm}$ using an external standard.

\section{Evaluation of DPPH radical scavenging activity}

The scavenging effect against the DPPH் radical was carried out according to Dong et al. (2012). $1 \mathrm{~mL}$ of extract at concentration of $10 \mathrm{mg} / \mathrm{mL}$ was mixed with $2.7 \mathrm{~mL}$ of methanolic solution of 2,2-diphenyl-1-picrylhydrazyl (DPPH) radicals at concentration of $6 \mu \mathrm{mol} / \mathrm{L}$. The mixture was incubated in the dark for $60 \mathrm{~min}$. Then the absorbance of the mixture was measured at $517 \mathrm{~nm}$. The ability to scavenge DPPH radicals was expressed as follow: $\begin{aligned} \text { DPPH inhibition }(\%)= & {\left.\left[\left(\mathrm{A}_{\text {control }}-\mathrm{A}_{\text {sample }}\right) / \mathrm{A}_{\text {control }}\right)\right] } \\ & \times 100\end{aligned}$

\section{Evaluation of ABTS radical scavenging activity}

The scavenging effect against the ABTS radical was carried out as described earlier (Gạsecka et al. 2015). A mixture of $7 \mathrm{~mol} / \mathrm{L}$ ABTS (2,2'-azino-bis-(3-ethylbenzothiazoline-6-sulfonic acid) diammonium salt) and $2.45 \mathrm{~mol} / \mathrm{L}$ potassium persulfate solution was kept in darkness overnight to generate radicals. Then $100 \mu \mathrm{L}$ of methanolic extract was mixed with the ABTS solution. After $10 \mathrm{~min}$, the absorbance was measured at $734 \mathrm{~nm}$. The radical scavenging activity was calculated according to the formula above.

\section{Extraction and determination of ergosterol}

The extraction procedure was according to Perkowski et al. (2008) with some modification. The mixture of mushroom samples, pure methanol and $2 \mathrm{M} \mathrm{NaOH}$ were irradiated twice in a microwave oven for $15 \mathrm{~s}$, cooled, and mixed with $1 \mathrm{M} \mathrm{HCl}$. Then the mixture was extracted with pentane three times. Analyses were carried out in an ACQUITY UPLC H-Class System coupled with a PDA e $\lambda$ Detector (Waters Corporation, Milford, MA, USA) using an ACQUITY UPLC HSS T3 $\mathrm{C}_{18}$ column $(150 \mathrm{~mm} \times$ $2.1 \mathrm{~mm}$, particle size $1.8 \mu \mathrm{m}$ ) (Waters, Ireland) and $1.7 \mathrm{~m}$ ACQUITY UPLC BEH C18 VanGuard Pre-column (Waters, Ireland). The mobile phase was a mixture of methanol, acetonitrile and water (v:v:v; 85:10:5). The isocratic elution with the flow rate of $0.5 \mathrm{~mL} / \mathrm{min}$ was applied.

\section{Preparation of samples for analysis of element contents}

Both dried and fresh samples were digested with $7 \mathrm{~mL}$ of concentrated nitric acid (65\% nitric acid, Merck, Darmstadt, Germany) in closed Teflon containers in the microwave digestion system Mars 6 Xpress (CEM, Matthews, USA). Samples were then filtered through paper filters and diluted with water to a final volume of $15.0 \mathrm{~mL}$. Each of the samples was processed in 3 replicates.

\section{Instruments and quality control}

The inductively coupled plasma optical emission spectrometer Agilent 5110 ICP-OES (Agilent, USA) was used for determination of 40 elements (Al, Ba, Be, Ca, Cd, Ce, $\mathrm{Cr}, \mathrm{Cu}, \mathrm{Dy}, \mathrm{Er}, \mathrm{Eu}, \mathrm{Fe}, \mathrm{Gd}, \mathrm{Hg}, \mathrm{Ho}, \mathrm{Ir}, \mathrm{K}, \mathrm{La}, \mathrm{Lu}, \mathrm{Mg}, \mathrm{Mn}$, $\mathrm{Na}, \mathrm{Nd}, \mathrm{Ni}, \mathrm{P}, \mathrm{Pb}, \mathrm{Pr}, \mathrm{Rb}, \mathrm{Sb}, \mathrm{Sc}, \mathrm{Se}, \mathrm{Sm}, \mathrm{Sn}, \mathrm{Sr}, \mathrm{Tb}, \mathrm{Tl}$, $\mathrm{Tm}, \mathrm{Y}, \mathrm{Yb}, \mathrm{Zn}$ ) under common conditions (see Online Resource). ICP commercial analytical standards-mixed mono- and multi-elemental (Romil, England)_-were used for the calibration. The selected wavelengths and validation parameters were as follows: the detection limits obtained follow 3-sigma criteria at the level of $0.0 \mathrm{X} \mathrm{mg} / \mathrm{kg}$ dry weight (DW); precision and upper range of calibration curves are presented in Table 2. Uncertainty for the complete analytical process (including sample preparation) was at the level of $20 \%$. Traceability was checked using the standard reference materials CRM S-1 = loess soil; CRM NCSDC $(73,349)=$ bush branches and leaves; CRM 2709 = soil; CRM 405 = estuarine sediments; and CRM 667 = estuarine sediments with the recovery acceptable for all the elements (80-120\%).

\section{Statistical analysis}

The results in tables and in figures were expressed as the mean value of three replicates $(n=3)$ and the standard deviation. Differences between mean values were evaluated by one-way analysis of variance (ANOVA) followed 
by post hoc Tukey's test. Statistical analysis was performed using STATISTICA 13.1.

\section{Results and discussion}

\section{Total phenolic content}

Total phenolic content was nearly two-fold higher in $H$. erinaceus than in L. scabrum (Fig. 1). TP content in $H$. erinaceus was lower than in the study presented by Yildiz et al. (2015). The drying method significantly affected TP content in both species. The decrease was confirmed for each drying temperature in comparison to fresh samples. For $H$. erinaceus it was a $17 \%$ reduction of TP (from 3.79 to $3.14 \mathrm{mg} / \mathrm{g} \mathrm{DW}$ ), while for L. scabrum it was a $40 \%$ reduction of TP (from 1.89 to $1.14 \mathrm{mg} / \mathrm{g} \mathrm{DW}$ ) at $70{ }^{\circ} \mathrm{C}$ in comparison to fresh. The results were in agreement with some studies on mushrooms, fruits and seeds, which contradict the reduction of TP under high-temperature drying (Juhaimi et al. 2018; Sim et al. 2017). The loss of TP (up to $25 \%$ ) during drying at high-temperature was also confirmed for edible mushroom Phlebopus colossus (Liaotrakoon and Liaotrakoon 2018).

Phenolics are molecules sensitive to temperature, and the changes of the content (both reduction and increase) with different drying temperature was indicated (Jaworska et al. 2014; Jiang et al. 2017; Sim et al. 2017; Yang et al. 2017). The oxygen atmosphere was responsible for their oxidation (Hamrouni-Sellami et al. 2012). In Grifola frondosa mycelia the drying in an oven at $70{ }^{\circ} \mathrm{C}$ reduced the TP content only from 17.0 to $16.6 \mathrm{mg} \mathrm{GAE} / \mathrm{g}$ (Sim et al. 2017). In Lentinula edodes an increase of TP was observed under hot air drying (Yang et al. 2017), because the phenolic compounds are substrates of lignin, whose more intense accumulation was observed as a result of high temperature drying. The reduction of phenolic compounds during drying may be the result of the activation of oxidative enzymes (polyphenol oxidase and peroxidase) (An et al. 2016) and the result of changes in the structure of the phenolic compounds (Toor and Savage 2006). Sezer et al. (2017) did not find any relation between TP and drying temperate of mushrooms. Oven drying at $43{ }^{\circ} \mathrm{C}$ did not affect TP or total flavonoid content in Pleurotus ostreatus (Mutukwa et al. 2019). On the other hand, drying at air temperature for 7 days significantly increased TP (from 8.77 to $119.8 \mathrm{mg} \mathrm{GAE} / \mathrm{g}$ ) in the mushroom Amanita zambiana due to the better extractability of bound polyphenols as a result of cell wall destruction after drying (Reid et al. 2017). Jaworska et al. (2014) also found that TP was elevated; however, total flavonoids were lost in $\mathrm{Bo}$ letus edulis during drying. Šumić et al. (2017) suggested that increase of temperature significantly decreased TP in Cantharellus cibarius, but they predicted that simultaneous use of temperature of $55^{\circ} \mathrm{C}$ and vacuum pressure $(10 \mathrm{kPa})$ would preserve phenolic compounds and cause their increase. A study on the effect of drying temperature on TP in jujube fruits showed that phenolics were rather stable at $55^{\circ} \mathrm{C}$ and only a small reduction of $\mathrm{TP}$ content was observed, but the drying and storage at ambient temperature elevated TP (Pu et al. 2018). In citrus seeds the drying process significantly affected TP content (Juhaimi et al. 2018). The temperatures of 60 and $70{ }^{\circ} \mathrm{C}$ elevated or reduced the TP content depending on the citrus seeds, but for all analyzed samples a significant drop was confirmed at $80{ }^{\circ} \mathrm{C}$ (Juhaimi et al. 2018).

In the profile of $H$. erinaceus, caffeic, chlorogenic, ferulic, gallic, 4-hydroxybenzoic, salicylic, sinapic, syringic, $t$-cinnamic and vanillic acid were quantified (Table 1). Gallic acid was the prevalent phenolic acid in the profile of H. erinaceus $(21.5 \mu \mathrm{g} / \mathrm{g} \mathrm{DW})$. In comparison to our earlier study some phenolic compounds were not detected
Fig. 1 Impact of drying temperature on total phenolic content

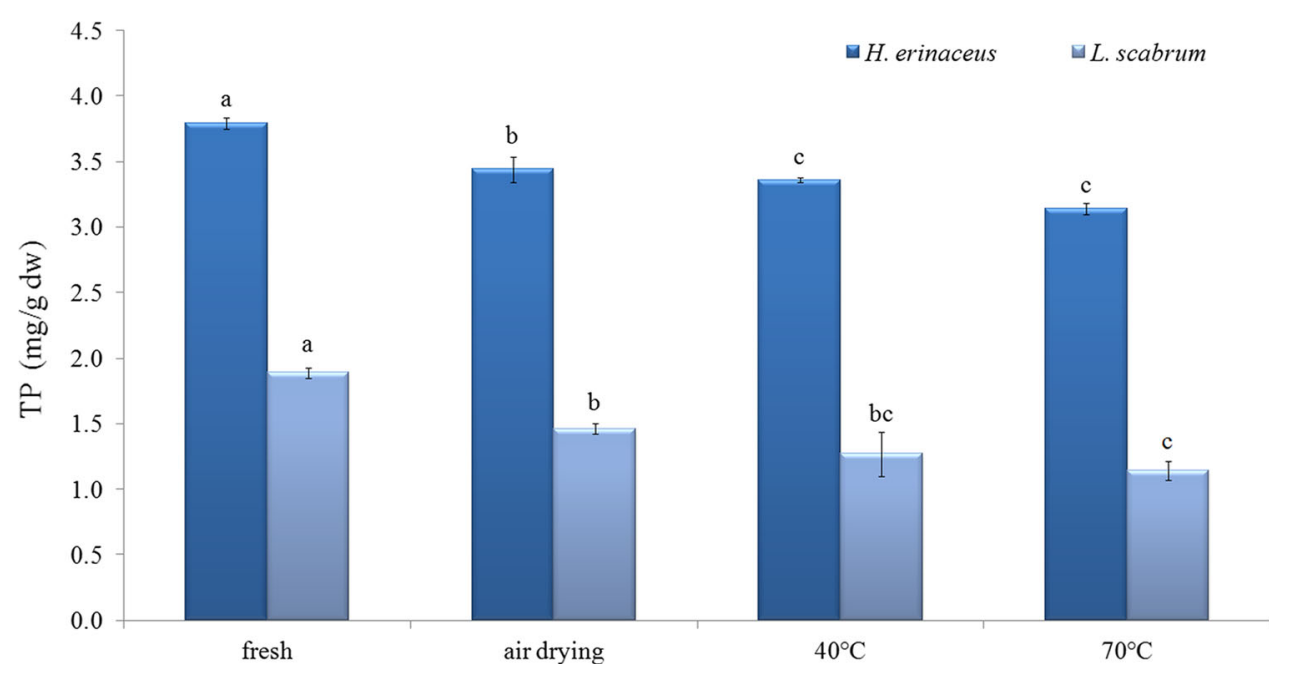


Table 1 Phenolic acid content ( $\mu \mathrm{g} / \mathrm{g}$ DW)in fruiting bodies of H. erinaceus and L. scabrum at different temperature of drying

\begin{tabular}{|c|c|c|c|c|c|c|c|}
\hline a & Caffeic & Chlorogenic & $\begin{array}{l}2,5- \\
\text { Dihydroxybenzoic }\end{array}$ & Ferulic & Galic & $\begin{array}{l}\text { 4- } \\
\text { Hydroxubenzoic }\end{array}$ & Protocatechiuc \\
\hline \multicolumn{8}{|c|}{ H. erinaceus } \\
\hline Fresh & $4.430^{\mathrm{a}} \pm 0.153$ & $2.688^{\mathrm{a}} \pm 0.147$ & nd & $6.254^{\mathrm{a}} \pm 0.146$ & $21.508^{\mathrm{a}} \pm 0.615$ & $5.538^{\mathrm{c}} \pm 0.263$ & nd \\
\hline $\begin{array}{l}\text { Air } \\
\text { drying }\end{array}$ & $0.120^{\mathrm{b}} \pm 0.029$ & $1.104^{\mathrm{c}} \pm 0.129$ & nd & $1.246^{\mathrm{b}} \pm 0.098$ & $11.365^{\mathrm{d}} \pm 0.459$ & $5.439^{c} \pm 0.210$ & nd \\
\hline $40{ }^{\circ} \mathrm{C}$ & $0.124^{\mathrm{b}} \pm 0.011$ & $1.275^{\mathrm{bc}} \pm 0.177$ & nd & $1.436^{\mathrm{b}} \pm 0.095$ & $13.872^{\mathrm{c}} \pm 0.199$ & $6.267^{b} \pm 0.166$ & nd \\
\hline $70{ }^{\circ} \mathrm{C}$ & $0.142^{\mathrm{b}} \pm 0.006$ & $1.444^{\mathrm{b}} \pm 0.112$ & nd & $1.571^{\mathrm{b}} \pm 0.234$ & $15.445^{\mathrm{b}} \pm 0.520$ & $6.961^{\mathrm{a}} \pm 0.158$ & nd \\
\hline \multicolumn{8}{|c|}{ L. scabrum } \\
\hline Fresh & $0.333^{\mathrm{a}} \pm 0.210$ & $0.228^{\mathrm{a}} \pm 0.014$ & $0.625^{\mathrm{a}} \pm 0.034$ & $0.185^{\mathrm{a}} \pm 0.016$ & nd & $0.68^{\mathrm{a}} \pm 0.034$ & $5.039^{\mathrm{a}} \pm 0.124$ \\
\hline $\begin{array}{l}\text { Air } \\
\text { drying }\end{array}$ & $0.324^{\mathrm{ab}} \pm 0.003$ & $0.233^{\mathrm{a}} \pm 0.009$ & $0.576^{\mathrm{ab}} \pm 0.008$ & $0.148^{b} \pm 0.012$ & nd & $0.708^{\mathrm{a}} \pm 0.008$ & $4.650^{\mathrm{b}} \pm 0.116$ \\
\hline $40{ }^{\circ} \mathrm{C}$ & $0.293^{\mathrm{bc}} \pm 0.130$ & $0.214^{\mathrm{a}} \pm 0.013$ & $0.541^{\mathrm{bc}} \pm 0.017$ & $0.129^{b} \pm 0.006$ & nd & $0.657^{\mathrm{ab}} \pm 0.014$ & $4.185^{\mathrm{c}} \pm 0.061$ \\
\hline $70{ }^{\circ} \mathrm{C}$ & $0.284^{\mathrm{c}} \pm 0.007$ & $0.182^{b} \pm 0.006$ & $0.500^{\mathrm{c}} \pm 0.008$ & $0.123^{\mathrm{b}} \pm 0.002$ & nd & $0.623^{\mathrm{b}} \pm 0.009$ & $4.146^{\mathrm{c}} \pm 0.061$ \\
\hline & Salicylic & Sinapic & Syringic & $t$-Cyn & amic & anilc & Sum \\
\hline H. erinace & & & & & & & \\
\hline Fresh & $5.286^{\mathrm{a}} \pm 0.2$ & $0.583^{\mathrm{d}} \pm$ & $1.620^{\mathrm{a}}$ & 0.096 & )$^{\mathrm{a}} \pm 0.011$ & $308^{\mathrm{a}} \pm 0.183$ & $64.763^{\mathrm{a}} \pm 1.066$ \\
\hline Air drying & $1.047^{\mathrm{b}} \pm 0.0$ & $2.152^{\mathrm{c}} \pm$ & $1.137^{\mathrm{b}}$ & 0.116 & ${ }^{\mathrm{b}} \pm 0.010$ & $531^{\mathrm{d}} \pm 0.156$ & $26.371^{c} \pm 0.858$ \\
\hline $40{ }^{\circ} \mathrm{C}$ & $1.141^{\mathrm{b}} \pm 0.1$ & $2.554^{\mathrm{b}} \pm$ & $1.246^{\mathrm{b}}$ & 0.105 & $2^{\mathrm{b}} \pm 0.145$ & $976^{\mathrm{c}} \pm 0.097$ & $31.163^{\mathrm{b}} \pm 0.184$ \\
\hline $70{ }^{\circ} \mathrm{C}$ & $1.363^{\mathrm{b}} \pm 0.0$ & $2.948^{\mathrm{a}} \pm$ & $1.359^{\mathrm{b}}$ & 0.076 & $2^{\mathrm{b}} \pm 0.015$ & $264^{\mathrm{b}} \pm 0.128$ & $34.800^{\mathrm{b}} \pm 1.014$ \\
\hline L. scabrun & & & & & & & \\
\hline Fresh & $0.219^{\mathrm{a}} \pm 0.0$ & nd & $0.558^{\mathrm{a}}$ & 0.023 & $5^{a} \pm 0.267$ & $166^{\mathrm{a}} \pm 0.060$ & $22.289^{\mathrm{a}} \pm 0.539$ \\
\hline Air drying & $0.219^{\mathrm{a}} \pm 0.0$ & nd & $0.535^{\mathrm{ab}}$ & 0.010 & $b^{b} \pm 0.746$ & $978^{\mathrm{b}} \pm 0.010$ & $19.536^{\mathrm{b}} \pm 0.712$ \\
\hline $40{ }^{\circ} \mathrm{C}$ & $0.227^{\mathrm{a}} \pm 0.0$ & nd & $0.531^{\mathrm{ab}}$ & 0.010 & $4^{c} \pm 0.267$ & $964^{\mathrm{b}} \pm 0.009$ & $17.424^{\mathrm{c}} \pm 0.279$ \\
\hline $70{ }^{\circ} \mathrm{C}$ & $0.220^{\mathrm{a}} \pm 0.0$ & nd & $0.506^{\mathrm{b}}$ & 0.012 & $t^{\mathrm{a}} \pm 0.106$ & $942^{\mathrm{b}} \pm 0.011$ & $16.659^{\mathrm{c}} \pm 0.183$ \\
\hline
\end{tabular}

Mean values $(\mathrm{n}=3$ ) and standard deviations; values within columns for each species of mushroom separately followed by the different letters are significantly different $(P<0.05)$ according to Tukey's HSD test (ANOVA)

(Gąsecka et al. 2016). To our knowledge, the composition of the phenolic compounds of $H$. erinaceus has been studied in only a few works. Gallic, ferulic, syringic and vanillic acids were quantified in another study as well (Yildiz et al. 2015), while 4-hydroxybenzoic, ferulic and syringic acids were detected by Li et al. (2012). The drying temperature resulted in the reduction of the content of the acids (from 2 to 37-fold). However, the content of 4-hydroxybenzoic and sinapic acid increased, achieving the highest value at $70{ }^{\circ} \mathrm{C}$. No significant changes in the content of caffeic, ferulic, salicylic, syringic and $t$-cinnamic acids between different drying temperatures were observed. In the profile of phenolic acids of $L$. scabrum $t$ cinnamic and protocatechuic acids were dominant. Additionally, fruiting bodies were characterized by presence of caffeic, chlorogenic, 2,5-dihydroxybenzoic, ferulic, 4-hydroxybenzoic, salicylic, syringic and vanillic acids. Nowacka et al. (2014) also found caffeic, ferulic, 4-hydroxybenzoic and protocatechuic acids in fruiting bodies of $L$. scabrum. The drying did not affect salicylic acids, but contents of other acids were lower in dried samples. There were no significant changes in the content of ferulic, syringic and vanillic acids between different temperatures of drying. Only air drying had no impact on caffeic, chlorogenic, 2,5-dihydroxybenzoic, 4-hydroxybenzoic and syringic acids. For other acids drying reduced the content. For both species a significant drop of total phenolic acids (sum) was confirmed in drying samples in comparison to fresh samples. Knowledge of changes in the phenolic profile of mushrooms under the drying is very scarce. However, the results obtained for various fruits and vegetables indicated the effect of the drying temperature on the content of phenolic acids. In black rice ferulic, caffeic, $p$-coumaric and gallic acids were found to be thermally unstable (Lang et al. 2019). Other changes were observed in jujube fruits, because the content of chlorogenic, $p$-hydroxybenzoic, caffeic, $p$-coumaric and ferulic acids in dried jujube fruits was significantly higher than in fresh products (Pu et al. 2018). The contents of phenolic compounds of citrus seeds were modified by drying temperate (Juhaimi et al. 2018). Contents of gallic and 3,4 dihydroxybenzoic acids increased at 60 and $70{ }^{\circ} \mathrm{C}$, while the content decreased at $80{ }^{\circ} \mathrm{C}$. The content of caffeic, $p$ coumaric, trans-ferulic, and syringic acids changed during 
drying, but both elevation and reduction of the content were observed (Juhaimi et al. 2018). The loss of phenolic compounds may be a result of activation of oxidative enzymes such as polyphenol oxidase and peroxidase (An et al. 2016), and changes in chemical structure of phenolic compounds via binding them to proteins (Toor and Savage 2006). Additionally, in mushrooms during drying, morphological changes may occur in fruiting bodies associated with lignification that affect the phenolic compounds, which are substrates of the lignin (Yang et al. 2017).

\section{Antioxidant activity}

The ability of $H$. erinaceus and $L$. scabrum to scavenge DPPH and ABTS radicals is shown in Figs. 2 and 3. Higher potential to scavenge free radicals was exhibited by $H$. erinaceus. The drying resulted in reduction of radical scavenging ability. The scavenging activity for both species was in the order: fresh samples $>$ air-dried samples $>$ samples dried at $40{ }^{\circ} \mathrm{C}>$ samples dried at $70{ }^{\circ} \mathrm{C}$. The inhibition of DPPH radicals decreased from 76 to $53 \%$ for $H$. erinaceus and from 70 to $47 \%$ for L. scabrum after drying (mainly from $40{ }^{\circ} \mathrm{C}$ in comparison to fresh samples). The inhibition of ABTS radicals decreased from 68 to $45 \%$ for $H$. erinaceus and from 66 to $45 \%$ for $L$. scabrum. The results were in agreement with those of Liaotrakoon and Liaotrakoon (2018), who demonstrated a drastic reduction in the ability to scavenge DPPH radicals during drying of $P$. colossus. The drying in an oven also significantly reduced DPPH radical scavenging activity of G. frondosa in comparison to fresh mushroom (Sim et al. 2017). Free radical scavenging activity expressed increased from 27.23 to $84.06 \%$ for P. ostreatus and from 33.22 to $76.46 \%$ for Agaricus bisporus in non-dried samples and
Fig. 2 DPPH radical scavenging activity (RSA, \%) of fresh and dried samples

Fig. 3 ABTS radical scavenging activity (RSA, \%) of fresh and dried samples
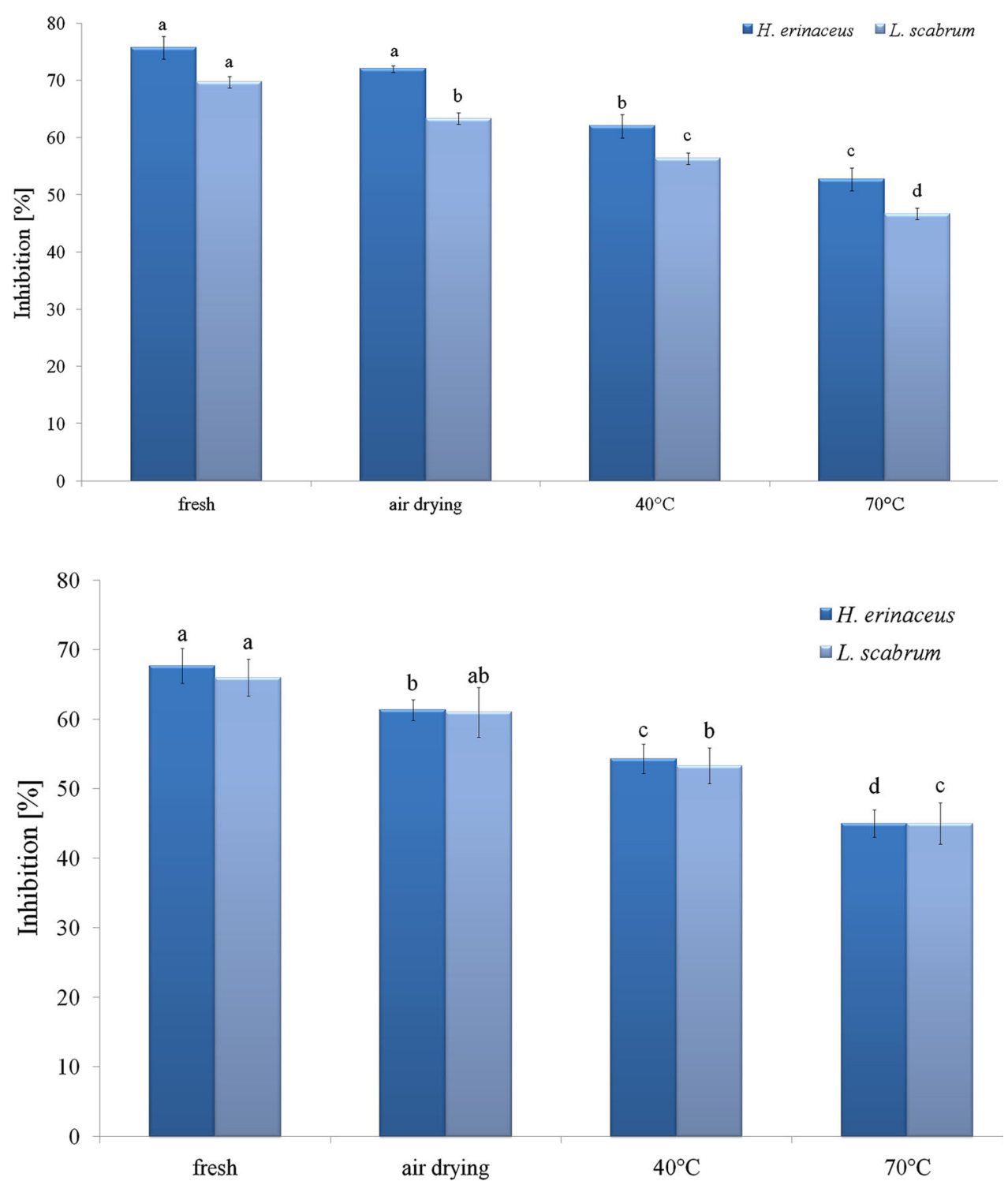
those dried at $80{ }^{\circ} \mathrm{C}$ (Reid et al. 2017). An increase of antioxidant activity during drying was also observed for $B$. edulis (Jaworska et al. 2014). The air-dried samples of okra showed lower antioxidant activity in comparison to fresh samples and TP was highly correlated with DPPH-scavenging ability (Juhaimi et al. 2018). However, in citrus seeds the drying process at 60 and $70{ }^{\circ} \mathrm{C}$ enhanced antioxidant activity while at $80{ }^{\circ} \mathrm{C}$ a decrease was observed (Juhaimi et al. 2018). The ability to scavenge free radicals is connected with phenolic compounds (Šumić et al. 2017). Additionally, Sim et al. (2017) suggested that heating of the mycelium interrupts its ability to donate hydrogen.

\section{Organic acids}

Identification of the quantitative analysis of the main organic acids found in fruits, vegetables and mushrooms is considered very important for the assessment of their quality. These acids affect not only the taste, but also their stability, nutrition, acceptability and maintaining quality (Igual et al. 2012; Gao et al. 2012, Colina-Coca et al. 2014, Barros et al. 2013). The beneficial health effects and bioactive properties of some organic acids (e.g. tartaric, malic, citric or succinic acids) are well-known and include antioxidant and antimicrobial, and acidifying properties (Barros et al. 2013; Valentão et al. 2005; Stojković et al. 2017). Metabolites play an important role in mushroom flavour (Ribeiro et al. 2006). Organic acids are more stable during processing and storage than other components such as pigments and flavour compounds (Fernandes et al. 2014). However, information with respect to how their content is affected by various drying methods was, to our knowledge, not available.

The major content of organic acids was observed for fresh mushroom samples, in both studied species (Table 2). Quinic and acetic acids were present in the largest amount in $H$. erinaceus samples (119.22 and $88.18 \mu \mathrm{g} / \mathrm{g} \mathrm{DW})$, representing 55.78 and $41.26 \%$, respectively, of the total organic acid content. In L. scabrum samples oxalic, succinic and citric acids were dominant $(148.19,34.10$ and $28.37 \mu \mathrm{g} / \mathrm{g} \mathrm{DW}$ ), and accounted for $70.34,16.19$ and $13.47 \%$, respectively. The drying process under different temperatures significantly affected the content of organic acids compared to fresh mushroom samples (Table 2). The content of total analysed organic acids in dried samples of H. erinaceus was $\sim 2.4$ to 6.9-fold lower (from 213.73 (fresh) to 73.74 and 71.62 for air and $40{ }^{\circ} \mathrm{C}$ drying, respectively, while under $70{ }^{\circ} \mathrm{C}$ this fall was to $36.96 \mu \mathrm{g} / \mathrm{g}$ DW). In the case of $L$. scabrum this decrease was definitely higher than that observed in $H$. erinaceus and ranged from $\sim 5.8$ to $\sim 35$-fold (from 210.66 to $31.44,6.12$ and $4.74 \mu \mathrm{g} / \mathrm{g}$ DW under air, $40{ }^{\circ} \mathrm{C}$ and $70{ }^{\circ} \mathrm{C}$ drying process method, respectively). What should be noted is, that

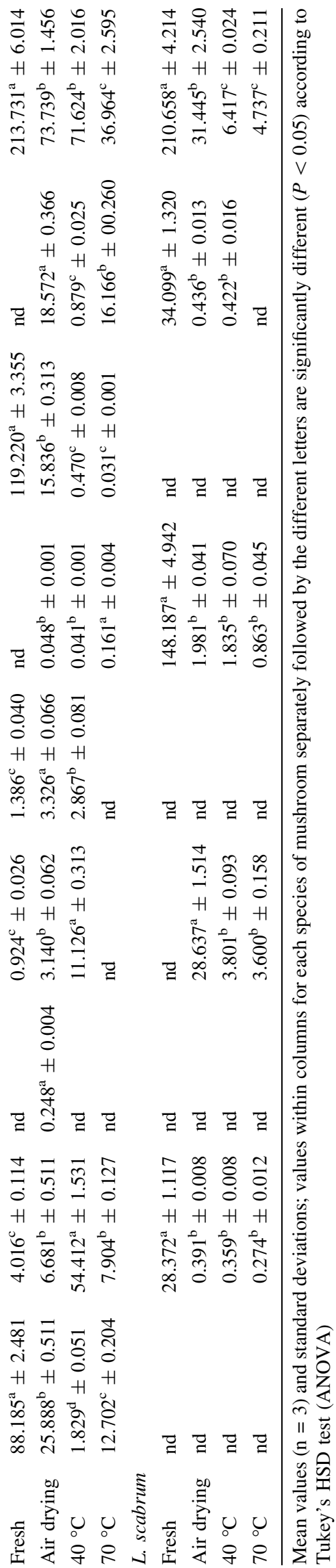


significant decreases were particularly observed for dominant acids obtained in mushroom species samples, even above $95 \%$ (e.g. content of quinic acid in $H$. erinaceus decreased from 119.22 in fresh samples to $0.03 \mu \mathrm{g} / \mathrm{g} \mathrm{DW}$ in samples dried under $70{ }^{\circ} \mathrm{C}$ and oxalic acid in L. scabrum where the decrease ranged from 148.19 in fresh samples to $0.86 \mu \mathrm{g} / \mathrm{g} \mathrm{DW}$ in samples dried under $70{ }^{\circ} \mathrm{C}$. As can be seen, the drying treatments led to a significant decrease $(p<0.05)$ in the content of major acids and their total sum, which is also connected with the processing method (higher temperature lower content of dominant acid). In $\mathrm{H}$. erinaceus samples, organic acids such as malic, citric, succinic and lactic showed significant differences, associated with their content increase. The content of malic acid increased more than twofold (from 1.39 to 3.33 and 2.87 under air and $40{ }^{\circ} \mathrm{C}$ process drying, respectively). The increase in the amount of malic acid extracted from samples treated in the medium dryness process may be caused by activation of its metabolic formation during the glycolytic pathway as a product of the transformation of succinic acid, obtained data for mushrooms correspond with the results described in the literature for other vegetables and fruits (Colina-Coca et al. 2014; Gao et al. 2012). This could be an effect similar to that described by Slatnar et al. (2011). In dried samples of fig fruits, the organic acids were more concentrated, because of lower water content (Slatnar et al. 2011). However, for L. scabrum only a decrease in the content of the studied acids was observed as a consequence of drying under higher temperature, which is likely to be connected with decomposition and degradation of the studied acids (Priecina et al. 2018).

\section{Ergosterol}

Ergosterol was detected in all samples, with the highest level in fresh samples (Fig. 4). Differences in ergosterol content were found between fresh and dried samples. All methods of drying reduced the content of the sterol. The strongest effect was confirmed at $70{ }^{\circ} \mathrm{C}$ for $H$. erinaceus and L. scabrum. The drop was about 50 and $48 \%$ respectively. Ergosterol is the principal sterol in mushrooms with content related to the species. Losses of the content under drying were detected in some studies (Bernaś 2017; Sławińska et al. 2016), while drying in low temperature indicated that ergosterol content was lower in $15^{\circ} \mathrm{C}$ than $5{ }^{\circ} \mathrm{C}$ and $10{ }^{\circ} \mathrm{C}$ (Vallespir et al. 2019). The studies on $A$. bisporus confirmed about $30 \%$ loss of ergosterol content in air-dried mushrooms in comparison to fresh samples (Bernaś 2017). Additionally, the study revealed that drying method and temperature of storage after drying significantly affected the reduction of the ergosterol level. A decrease of ergosterol content was also found in dried samples of $A$. bisporus and other species of mushroom- $P$. ostreatus and L. edodes (Sławińska et al. 2016). Moreover, in the case of hot air dried mushrooms their ability to produce vitamin D after drying under UVB irradiation was confirmed. Storage temperature and UV radiation influence the stability of the ergosterol extract-higher oxidation and production of ergosterol peroxides occurs with increasing temperature, while UV radiation promotes transformation into vitamin D (Villares et al. 2014). Thus the losses of ergosterol in samples of L. scabrum and $H$. erinaceus were the effect of drying method, the time of storage and access to light.

\section{Element contents}

In selected mushrooms the analysis of 40 elements was performed. The obtained results were divided into the following groups of elements: minerals, trace elements, heavy rare earth elements (HREEs) and light rare earth elements (LREEs) (Table 3). The results obtained for
Fig. 4 Ergosterol content in fresh and dried samples

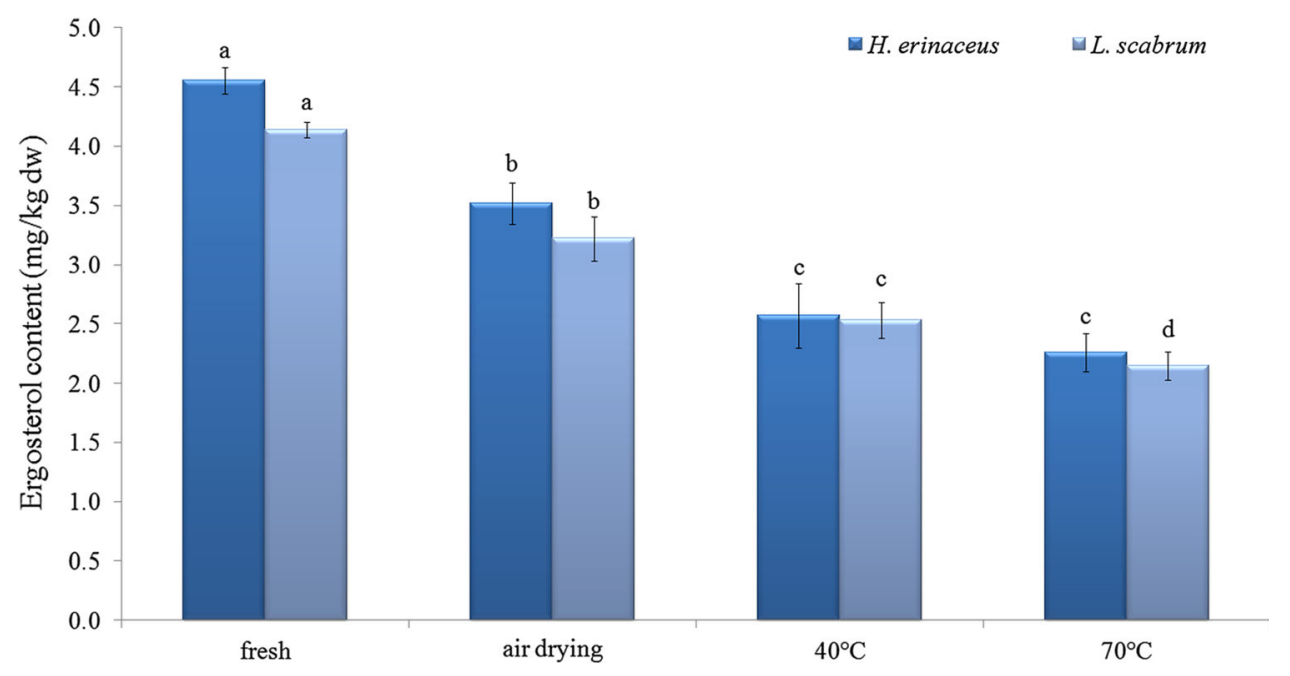


Table 3 Content of elements (mg/kg DW) in H. erinaceus and L. scabrum exposed to different temperatures of drying process

\begin{tabular}{|c|c|c|c|c|c|c|c|c|}
\hline \multirow[t]{3}{*}{ Element } & \multicolumn{4}{|l|}{ H. erinaceus } & \multicolumn{4}{|l|}{ L. scabrum } \\
\hline & \multirow[t]{2}{*}{ Fresh weight } & \multicolumn{3}{|c|}{ Temperature of drying $\left({ }^{\circ} \mathrm{C}\right)$} & \multirow[t]{2}{*}{ Fresh weight } & \multicolumn{3}{|c|}{ Temperature of drying $\left({ }^{\circ} \mathrm{C}\right)$} \\
\hline & & Air drying & 40 & 70 & & Air drying & 40 & 70 \\
\hline \multicolumn{9}{|l|}{ Minerals } \\
\hline $\mathrm{Ca}$ & $406.66^{\mathrm{a}}$ & $387.14^{\mathrm{b}}$ & $361.43^{\mathrm{c}}$ & $329.39^{\mathrm{d}}$ & $296.67^{\mathrm{a}}$ & $285.33^{\mathrm{b}}$ & $293.33^{\mathrm{ab}}$ & $180.83^{\mathrm{d}}$ \\
\hline $\mathrm{K}$ & $35,645^{\mathrm{a}}$ & $23,710^{\mathrm{a}}$ & $31,472^{\mathrm{a}}$ & $42,700^{\mathrm{a}}$ & $37,796^{\mathrm{a}}$ & $37,874^{\mathrm{a}}$ & $32,677^{\mathrm{b}}$ & $29,858^{\mathrm{c}}$ \\
\hline $\mathrm{Mg}$ & $922.00^{\mathrm{a}}$ & $907.26^{\mathrm{ab}}$ & $879.33^{\mathrm{b}}$ & $846.92^{c}$ & $807.93^{\mathrm{b}}$ & $875.96^{\mathrm{a}}$ & $844.46^{\mathrm{a}}$ & $789.43^{\mathrm{b}}$ \\
\hline $\mathrm{Na}$ & $246.91^{\mathrm{a}}$ & $236.94^{\mathrm{bc}}$ & $240.07^{\mathrm{ab}}$ & $229.27^{\mathrm{c}}$ & $221.53^{\mathrm{a}}$ & $215.48^{\mathrm{ab}}$ & $211.52^{\mathrm{b}}$ & $208.58^{\mathrm{b}}$ \\
\hline $\mathrm{P}$ & $6600^{\mathrm{a}}$ & $6374^{\mathrm{c}}$ & $6209^{c}$ & $6457^{\mathrm{b}}$ & $6365^{\mathrm{b}}$ & $6473^{\mathrm{a}}$ & $6498^{\mathrm{a}}$ & $6035^{\mathrm{c}}$ \\
\hline \multicolumn{9}{|c|}{ Trace elements } \\
\hline $\mathrm{Al}$ & $3.52^{\mathrm{c}}$ & $3.86^{\mathrm{a}}$ & $3.82^{\mathrm{a}}$ & $3.65^{\mathrm{b}}$ & $2.41^{\mathrm{a}}$ & $2.23^{\mathrm{b}}$ & $2.18^{\mathrm{c}}$ & $1.60^{\mathrm{d}}$ \\
\hline $\mathrm{Ba}$ & $1.90^{\mathrm{a}}$ & $1.92^{\mathrm{a}}$ & $1.81^{\mathrm{b}}$ & $1.60^{c}$ & $0.87^{\mathrm{a}}$ & $0.81^{\mathrm{b}}$ & $0.80^{\mathrm{c}}$ & $0.69^{\mathrm{d}}$ \\
\hline $\mathrm{Be}$ & $<0.01$ & $<0.01$ & $<0.01$ & $<0.01$ & $0.10^{\mathrm{a}}$ & $0.09^{\mathrm{a}}$ & $0.10^{\mathrm{a}}$ & $0.09^{\mathrm{a}}$ \\
\hline $\mathrm{Cd}$ & $1.53^{\mathrm{a}}$ & $1.32^{\mathrm{b}}$ & $1.31^{\mathrm{b}}$ & $1.08^{\mathrm{c}}$ & $0.55^{\mathrm{b}}$ & $0.53^{\mathrm{c}}$ & $0.55^{\mathrm{b}}$ & $0.64^{\mathrm{a}}$ \\
\hline $\mathrm{Cr}$ & $3.25^{\mathrm{a}}$ & $3.21^{\mathrm{b}}$ & $3.07^{\mathrm{c}}$ & $2.73^{\mathrm{d}}$ & $3.55^{\mathrm{b}}$ & $3.18^{\mathrm{c}}$ & $3.08^{\mathrm{d}}$ & $4.29^{\mathrm{a}}$ \\
\hline $\mathrm{Cu}$ & $32.9^{\mathrm{b}}$ & $33.3^{\mathrm{a}}$ & $32.8^{\mathrm{b}}$ & $33.3^{\mathrm{a}}$ & $19.6^{\mathrm{a}}$ & $18.1^{\mathrm{c}}$ & $19.5^{\mathrm{b}}$ & $17.0^{\mathrm{d}}$ \\
\hline $\mathrm{Fe}$ & $19.14^{\mathrm{a}}$ & $19.16^{\mathrm{a}}$ & $16.93^{\mathrm{a}}$ & $17.85^{\mathrm{a}}$ & $15.74^{\mathrm{a}}$ & $15.96^{\mathrm{a}}$ & $14.05^{\mathrm{b}}$ & $16.01^{\mathrm{a}}$ \\
\hline $\mathrm{Hg}$ & $0.49^{\mathrm{a}}$ & $0.49^{\mathrm{a}}$ & $0.47^{\mathrm{ab}}$ & $0.30^{\mathrm{b}}$ & $0.45^{\mathrm{a}}$ & $0.41^{\mathrm{b}}$ & $0.26^{\mathrm{d}}$ & $0.31^{\mathrm{c}}$ \\
\hline $\mathrm{Ir}$ & $0.16^{\mathrm{a}}$ & $0.14^{\mathrm{b}}$ & $0.13^{c}$ & $0.14^{\mathrm{b}}$ & $0.17^{\mathrm{b}}$ & $0.18^{\mathrm{a}}$ & $0.16^{\mathrm{c}}$ & $0.18^{\mathrm{a}}$ \\
\hline $\mathrm{Mn}$ & $17.24^{\mathrm{a}}$ & $14.32^{\mathrm{b}}$ & $15.32^{\mathrm{ab}}$ & $14.17^{\mathrm{b}}$ & $17.23^{\mathrm{a}}$ & $17.35^{\mathrm{a}}$ & $17.78^{\mathrm{a}}$ & $17.24^{\mathrm{a}}$ \\
\hline $\mathrm{Ni}$ & $2.08^{\mathrm{a}}$ & $2.06^{\mathrm{b}}$ & $1.98^{\mathrm{d}}$ & $2.01^{\mathrm{c}}$ & $1.35^{\mathrm{a}}$ & $1.28^{\mathrm{a}}$ & $1.36^{\mathrm{a}}$ & $1.62^{\mathrm{a}}$ \\
\hline $\mathrm{Pb}$ & $1.10^{\mathrm{a}}$ & $0.93^{\mathrm{ab}}$ & $0.91^{\mathrm{ab}}$ & $0.85^{\mathrm{b}}$ & $1.42^{\mathrm{a}}$ & $1.32^{\mathrm{c}}$ & $1.37^{\mathrm{b}}$ & $1.14^{\mathrm{d}}$ \\
\hline $\mathrm{Rb}$ & $36.01^{\mathrm{a}}$ & $34.02^{\mathrm{c}}$ & $35.12^{\mathrm{b}}$ & $30.29^{\mathrm{d}}$ & $35.94^{\mathrm{b}}$ & $35.55^{\mathrm{c}}$ & $36.41^{\mathrm{a}}$ & $32.91^{\mathrm{d}}$ \\
\hline $\mathrm{Sb}$ & $0.85^{\mathrm{b}}$ & $0.86^{\mathrm{a}}$ & $0.81^{\mathrm{c}}$ & $0.43^{\mathrm{d}}$ & $0.71^{\mathrm{b}}$ & $0.69^{c}$ & $0.62^{\mathrm{d}}$ & $0.90^{\mathrm{a}}$ \\
\hline $\mathrm{Se}$ & $0.97^{\mathrm{a}}$ & $0.87^{\mathrm{b}}$ & $0.86^{\mathrm{b}}$ & $0.49^{c}$ & $1.07^{\mathrm{a}}$ & $1.04^{\mathrm{a}}$ & $0.86^{\mathrm{c}}$ & $0.36^{\mathrm{d}}$ \\
\hline $\mathrm{Sn}$ & $0.30^{\mathrm{a}}$ & $0.28^{\mathrm{c}}$ & $0.29^{\mathrm{b}}$ & $0.28^{\mathrm{c}}$ & $0.22^{\mathrm{b}}$ & $0.21^{\mathrm{c}}$ & $0.22^{\mathrm{b}}$ & $0.24^{\mathrm{a}}$ \\
\hline $\mathrm{Sr}$ & $1.01^{\mathrm{c}}$ & $1.17^{\mathrm{b}}$ & $1.27^{\mathrm{a}}$ & $1.27^{\mathrm{a}}$ & $0.50^{\mathrm{c}}$ & $0.47^{\mathrm{d}}$ & $0.56^{\mathrm{b}}$ & $0.79^{\mathrm{a}}$ \\
\hline $\mathrm{Tl}$ & $0.26^{\mathrm{b}}$ & $0.24^{\mathrm{a}}$ & $0.28^{\mathrm{a}}$ & $0.26^{\mathrm{b}}$ & $0.23^{\mathrm{a}}$ & $0.23^{\mathrm{a}}$ & $0.22^{\mathrm{b}}$ & $0.11^{\mathrm{c}}$ \\
\hline $\mathrm{Zn}$ & $26.76^{\mathrm{a}}$ & $24.74^{\mathrm{c}}$ & $25.86^{\mathrm{b}}$ & $21.01^{\mathrm{d}}$ & $23.52^{\mathrm{c}}$ & $24.88^{\mathrm{b}}$ & $21.86^{\mathrm{d}}$ & $27.49^{\mathrm{a}}$ \\
\hline \multicolumn{9}{|l|}{ HREEs } \\
\hline Dy & $<0.01$ & $<0.01$ & $<0.01$ & $<0.01$ & $<0.01$ & $<0.01$ & $<0.01$ & $<0.01$ \\
\hline $\mathrm{Er}$ & $<0.01$ & $<0.01$ & $<0.01$ & $<0.01$ & $<0.01$ & $<0.01$ & $<0.01$ & $<0.01$ \\
\hline Ho & $<0.01$ & $<0.01$ & $<0.01$ & $<0.01$ & $<0.01$ & $<0.01$ & $<0.01$ & $<0.01$ \\
\hline $\mathrm{Lu}$ & $<0.01$ & $<0.01$ & $<0.01$ & $<0.01$ & $<0.01$ & $<0.01$ & $<0.01$ & $<0.01$ \\
\hline $\mathrm{Sc}$ & $<0.01$ & $<0.01$ & $<0.01$ & $<0.01$ & $<0.01$ & $<0.01$ & $<0.01$ & $<0.01$ \\
\hline $\mathrm{Tb}$ & $<0,01$ & $<0,01$ & $<0.01$ & $<0.01$ & $<0.01$ & $<0.01$ & $<0.01$ & $<0.01$ \\
\hline $\mathrm{Tm}$ & $0.06^{\mathrm{a}}$ & $0.05^{\mathrm{b}}$ & $0.06^{\mathrm{a}}$ & $0.05^{\mathrm{b}}$ & $0.04^{\mathrm{a}}$ & $0.03^{\mathrm{b}}$ & $0.04^{\mathrm{a}}$ & $0.04^{\mathrm{a}}$ \\
\hline $\mathrm{Y}$ & $<0.01$ & $<0.01$ & $<0.01$ & $<0.01$ & $<0.01$ & $<0.01$ & $<0.01$ & $<0.01$ \\
\hline $\mathrm{Yb}$ & $<0.01$ & $<0.01$ & $<0.01$ & $<0.01$ & $<0.01$ & $<0.01$ & $<0.01$ & $<0.01$ \\
\hline \multicolumn{9}{|l|}{ LREEs } \\
\hline $\mathrm{Ce}$ & $0.05^{\mathrm{a}}$ & $0.04^{\mathrm{b}}$ & $0.04^{\mathrm{b}}$ & $0.02^{\mathrm{c}}$ & $<0.01$ & $<0.01$ & $<0.01$ & $<0.01$ \\
\hline $\mathrm{Eu}$ & $0.02^{\mathrm{a}}$ & $0.02^{\mathrm{a}}$ & $0.02^{\mathrm{a}}$ & $0.02^{\mathrm{a}}$ & $<0.01$ & $<0.01$ & $<0.01$ & 0.05 \\
\hline Gd & $<0.01$ & $<0.01$ & $<0.01$ & $<0,01$ & $<0.01$ & $<0.01$ & $<0.01$ & $<0.01$ \\
\hline $\mathrm{La}$ & $0.05^{\mathrm{b}}$ & $0.06^{\mathrm{a}}$ & $0.05^{\mathrm{b}}$ & $0.05^{\mathrm{b}}$ & $0.06^{\mathrm{a}}$ & $0.05^{\mathrm{b}}$ & $0.04^{\mathrm{c}}$ & $0.05^{\mathrm{b}}$ \\
\hline $\mathrm{Nd}$ & $0.41^{\mathrm{a}}$ & $0.36^{\mathrm{b}}$ & $0.36^{\mathrm{b}}$ & $0.30^{\mathrm{c}}$ & $0.79^{\mathrm{a}}$ & $0.76^{\mathrm{b}}$ & $0.65^{\mathrm{c}}$ & $0.65^{\mathrm{c}}$ \\
\hline $\operatorname{Pr}$ & $0.27^{\mathrm{a}}$ & $0.26^{\mathrm{b}}$ & $0.20^{\mathrm{c}}$ & $0.21^{\mathrm{d}}$ & $0.14^{\mathrm{a}}$ & $0.14^{\mathrm{a}}$ & $0.12^{\mathrm{b}}$ & $0.11^{\mathrm{c}}$ \\
\hline $\mathrm{Sm}$ & $<0.01$ & $<0.01$ & $<0.01$ & $<0.01$ & $<0.01$ & $<0.01$ & $<0.01$ & $<0.01$ \\
\hline
\end{tabular}

Mean values $(n=3)$; identical superscripts in a row separately for each species of mushroom denote no significant $(\alpha<0.05)$ difference between mean values according to Tukey's HSD test (ANOVA); HREEs heavy rare earth elements, LREEs light rare earth elements 
minerals ( $\mathrm{Ca}, \mathrm{K}, \mathrm{Mg}, \mathrm{Na}$ and $\mathrm{P}$ ) show that the content of elements in fresh fruiting bodies was dependent on the species. The mushroom species richest in $\mathrm{Ca}, \mathrm{Mg}, \mathrm{Na}$ and $\mathrm{P}$ was $H$. erinaceus, while $L$. scabrum contained a higher content of $\mathrm{K}$. The temperature used during the drying reduced the content of $\mathrm{Ca}, \mathrm{Mg}$ and $\mathrm{P}$ in $H$. erinaceus, while in L. scabrum $\mathrm{Ca}, \mathrm{K}, \mathrm{Mg}, \mathrm{Na}$ and $\mathrm{P}$ content decreased after drying. It is difficult to explain why the content of selected elements decreased with an increase in drying temperature. One possible solution could be varied durability of metal complexes with metallothioneins (MTs) being a ubiquitous class of low molecular weight proteins (Muenger and Lerch 1985). Unfortunately, according to our present studies, such an explanation can be real for copper-MTs complexes only. Such complexes can be relatively easy to destroy because of the low durability of numerous MT in higher temperature what confirm analytical studies using a new method for MTs determination (Ryvolova et al. 2011). The results obtained for trace elements $(\mathrm{Al}, \mathrm{Ba}, \mathrm{Be}, \mathrm{Cd}, \mathrm{Cr}$, $\mathrm{Cu}, \mathrm{Fe}, \mathrm{Hg}$, Ir, Mn, Ni, Pb, Rb, Sb, Se, Sn, Sr, Tl, Zn) show that higher contents of them generally are accumulated in fresh fruiting bodies for $H$. erinaceus. The temperature of drying significantly modified the selected trace element contents similarly to the observation of Garba and Oviosa (2019), who dried Vernonia amygdalina using air, sun, oven and solar drying. The use of different drying methods (different temperatures) caused changes in the content of selected elements (minerals, $\mathrm{Fe}, \mathrm{Pb}, \mathrm{Cu}$ ). In spite of slight changes, the decrease in content of these elements was significant ( $\alpha=0.05$ ) for $\mathrm{Ba}, \mathrm{Cd}, \mathrm{Cr}, \mathrm{Hg}, \mathrm{Ir}, \mathrm{Mn}, \mathrm{Ni}, \mathrm{Rb}$, $\mathrm{Se}, \mathrm{Sn}$ and $\mathrm{Zn}$. The obtained results show the highest content of $\mathrm{Al}, \mathrm{Ba}, \mathrm{Cu}, \mathrm{Hg}, \mathrm{Pb}, \mathrm{Se}$ and $\mathrm{Tl}$ in L. scabrum fresh fruiting bodies and that the increase of temperature of drying was associated with a significant decrease in content of these toxic elements.

For the majority of HREEs, their content in fruit bodies of both species was below detection limits, with the exception of Tm, being in the range $0.03-0.06 \mathrm{mg} / \mathrm{kg} \mathrm{DW}$. Among LREEs determined in $H$. erinaceus, changes in the content of $\mathrm{Ce}, \mathrm{La}, \mathrm{Nd}$ and $\mathrm{Pr}$ with a reduction for $\mathrm{Ce}, \mathrm{Nd}$ and Pr with regard to different temperatures of drying were recorded. No changes were observed for $\mathrm{Eu}$, while $\mathrm{Gd}$ and $\mathrm{Sm}$ were below the limit of detection. A reduction of $\mathrm{La}$, $\mathrm{Nd}$ and $\mathrm{Pr}$ for L. scabrum exposed to increased temperature of drying was observed. The other LREEs ( $\mathrm{Eu}, \mathrm{Gd}, \mathrm{Nb}$ ) were below the limit of detection or no changes were observed.

The obtained results have shown no significant influence of different temperatures of the drying process on content of selected elements in $H$. erinaceus and L. scabrum fruiting bodies, which confirms the previous data described by Muyanja et al. (2014). In our opinion, changes in element contents (especially at $70{ }^{\circ} \mathrm{C}$ ) in mushroom bodies are possible mainly for volatile elements such as the herein studied Sb or Se, as was clearly observed, and also As, not analyzed here. In the case of volatile elements their loss is a common occurrence. Therefore before analysis of the above mentioned elements as well as $\mathrm{Hg}$, a subject of numerous studies of mushrooms, the selection of a suitable drying method or the use of a relatively low temperature is necessary (Hojdová et al. 2015). It is worth noting that a higher drying temperature reduces the time of this stage of sample preparation, although it may be associated with the loss not only of volatile elements but also of heavy metals such as $\mathrm{Pb}$ or $\mathrm{Zn}$ (Zhang et al. 2001).

Changes in element contents may be more associated with the form of elements than with their total concentration, which confirms the study of Chen et al. (2017a), who described the influence of speciation changes of $\mathrm{Cd}, \mathrm{Cr}$ and $\mathrm{Pb}$ after drying (hot air and freeze drying samples). Mushrooms dried in different ways may be characterized by various contents of numerous elements (Maray et al. 2018), whereas this does not apply to mushrooms dried by the same method but with different temperatures.

\section{Conclusion}

Drying is a process that allows the product to be stored for a longer time and during the off-season, especially for wild growing mushrooms. Drying is also a method of preservation allowing the product to be available all year round. However, temperature significantly affects the content of the analyzed bioactive compounds and antioxidant properties. Losses of TP, phenolic and organic acids and ergosterol content were observed. Changes in elements were probably connected with speciation changes. The obtained results suggested that losses of bioactive compounds probably diminish the pro-health properties of mushrooms.

Open Access This article is distributed under the terms of the Creative Commons Attribution 4.0 International License (http://crea tivecommons.org/licenses/by/4.0/), which permits unrestricted use, distribution, and reproduction in any medium, provided you give appropriate credit to the original author(s) and the source, provide a link to the Creative Commons license, and indicate if changes were made.

\section{References}

Akram K, Kwon J-H (2010) Food irradiation for mushrooms: a review. J Korean Soc Appl Biol Chem 53:257-265. https://doi. org/10.3839/jksabc.2010.041

Altmeyer PJ, Mattlies U, Pawlak F, Hoffmann K, Frosch PJ, Ruppert P, Wassilew SW, Horn T, Kreysel HW, Lutz G, Barth J, Rietzschel I, Joshi RK (1994) Antipsoriatic effects of fumaric acid derivatives. Results of a multicenter double-blind study in 
100 patients. J Am Acad Dermatol 30:977-981. https://doi.org/ 10.1016/S0190-9622(94)70121-0

An K, Zhao D, Wang Z, Wu J, Xu Y, Xiao G (2016) Comparison of different drying methods on Chinese ginger (Zingiber officinale Roscoe): changes in volatiles, chemical profile, antioxidant properties, and microstructure. Food Chem 197:1292-1300. https://doi.org/10.1016/j.foodchem.2015.11.033

Anibal C, Farenzena S, Rodríguez MS, Albertengo L (2015) Chemical composition and nutritional value of Argentine commercial edible mushrooms. J Verbrauch Lebensm 10(2):155-164. https://doi.org/10.1007/s00003-015-0937-9

Baati T, Horcajada P, Gref R, Couvreur P, Serre C (2011) Quantification of fumaric acid in liver, spleen and urine by high-performance liquid chromatography coupled to photodiodearray detection. J Pharm Biomed Anal 56(4):758-762. https:// doi.org/10.1016/j.jpba.2011.07.011

Barros L, Pereira C, Ferreira ICFR (2013) Optimized analysis of organic acids in edible mushrooms from portugal by ultra fast liquid chromatography and photodiode array detection. Food Anal Methods 6:309-316. https://doi.org/10.1007/s12161-0129443-1

Bernaś E (2017) Culinary-medicinal mushroom products as a potential source of vitamin D. Int $\mathrm{J}$ Med Mushrooms 19(10):925-936. https://doi.org/10.1615/IntJMedMushrooms. 2017024596

Brennan M, Le Port G, Gormley R (2000) Post-harvest treatment with citric acid or hydrogen peroxide to extend the shelf life of fresh sliced mushrooms. LWT-Food Sci Technol 33:285-289. https:// doi.org/10.1006/fstl.2000.0657

Chen C, Chen G, Wang S, Pei F, Hu Q, Zhao L (2017a) Speciation changes of three toxic elements in Lentinus edodes after drying and soaking. J Food Process Preserv 41(2):e12772. https://doi. org/10.1111/jfpp. 12772

Chen S, Tianqiao Y, Zhang Y, Su J, Jiao C, Xie Y (2017b) Anti-tumor and anti-angiogenic ergosterols from Ganoderma lucidum. Front Chem 5:85. https://doi.org/10.3389/fchem.2017.00085

Colina-Coca C, de Ancos B, Sánchez-Moreno C (2014) Nutritional composition of processed onion: s-alk(en)yl-L-cysteine sulfoxides, organic acids, sugars, minerals, and vitamin C. Food Bioprocess Technol 7:289-298. https://doi.org/10.1007/s11947013-1150-4

Dong J, Zhang M, Lu L, Sun L, Xu M (2012) Nitric oxide fumigation stimulates flavonoid and phenolic accumulation and enhances antioxidant activity of mushroom. Food Chem 135:1220-1225. https://doi.org/10.1016/j.foodchem.2012.05.055

Fernandes A, Barros L, Antonio AL, Barreira JCM, Oliveira MBPP, Martins A, Ferreira ICFR (2014) Using gamma irradiation to attenuate the effects caused by drying or freezing in Macrolepiota procera organic acids and phenolic compounds. Food Bioprocess Technol 7:3012-3021. https://doi.org/10.1007/ s11947-013-1248-8

Friedman M (2015) Chemistry, nutrition, and health-promoting properties of Hericium erinaceus (Lion's Mane) mushroom fruiting bodies and mycelia and their bioactive compounds. J Agric Food Chem 63:7108-7123. https://doi.org/10.1021/acs. jafc.5b02914

Gao Q-H, Wu Ch-S, Wang M, Xu B-N, Du L-J (2012) Effect of drying of jujubes (Ziziphus jujuba Mill.) on the contents of sugars, organic acids, $\alpha$-tocopherol, $\beta$-carotene, and phenolic compounds. J Agric Food Chem 60:9642-9648. https://doi.org/ $10.1021 / \mathrm{jf} 3026524$

Garba ZN, Oviosa S (2019) The effect of different drying methods on the elemental and nutritional composition of Vernonia amygdalina (bitter leaf). J Taibah Univ Sci 13:396-401. https://doi. org/10.1080/16583655.2019.1582148
Gąsecka M, Mleczek M, Siwulski M, Niedzielski P, Kozak L (2015) The effect of selenium on phenolics and flavonoids in selected edible white rot fungi. LWT-Food Sci Technol 63(1):726-731. https://doi.org/10.1016/j.lwt.2015.03.046

Gąsecka M, Mleczek M, Siwulski M, Niedzielski P, Kozak L (2016) Phenolic and flavonoid content in Hericium erinaceus, Ganoderma lucidum and Agrocybe aegerita under selenium addition. Acta Aliment Hung 45(2):301-309. https://doi.org/10.1556/066. 2016.45.2.18

Genkinger JM, Platz EA, Hoffman SC, Comstock GW, Helzlsouer KJ (2004) Fruit, vegetable, and antioxidant intake and all-cause, cancer, and cardiovascular disease mortality in a communitydwelling population in Washington County, Maryland. Am J Epidemiol 160(12):1223-1233. https://doi.org/10.1093/aje/ kwh339

Hamrouni-Sellami I, Rahali FZ, Rebey IB, Bourgou S, Limam F, Marzouk B (2012) Total phenolics, flavonoids, and antioxidant activity of sage (Salvia officinalis L.) plants as affected by different drying methods. Food Bioprocess Technol 6(3):806-817. https://doi.org/10.1007/s11947-012-0877-7

Heleno SA, Ferreira RC, Antonio AL, Queiroz MJRP, Barros L, Ferreira ICFR (2015) Nutritional value, bioactive compounds and antioxidant properties of three edible mushrooms from Poland. Food Biosci 11:48-55. https://doi.org/10.1016/j.fbio. 2015.04.006

Hojdová M, Rohovec J, Chrastný V, Penížek V, Navrátil T (2015) The influence of sample drying procedures on mercury concentrations analyzed in soils. Bull Environ Contam Toxicol 94(5):570-576. https://doi.org/10.1007/s00128-015-1521-9

$\mathrm{Hu}$ SH, Liang ZC, Chia YC, Lien JL, Chen KS, Lee MY, Wang JC (2006) Antihyperlipidemic and antioxidant effects of extracts from Pleurotus citrinopileatus. J Agric Food Chem 54:2103-2110

Igual M, García-Martínez E, Martín-Esparza ME, Martínez-Navarrete $\mathrm{N}$ (2012) Effect of processing on the drying kinetics and functional value of dried apricot. Food Res Int 47:284-290. https://doi.org/10.1016/j.foodres.2011.07.019

Jaworska G, Pogoń K, Bernaś E, Skrzypczak A (2014) Effect of different drying methods and 24-month storage on water activity, rehydration capacity, and antioxidants in Boletus edulis mushrooms. Dry Technol 32(3):291-300. https://doi.org/10.1080/ 07373937.2013 .824895

Jedidi IK, Ayoub IK, Philippe T, Bouzouita N (2017) Chemical composition and nutritional value of three Tunisian wild edible mushrooms. J Food Meas Charact 11(4):2069-2075. https://doi. org/10.1007/s11694-017-9590-6

Jiang N, Liu C, Li D, Zhang Z, Liu C, Wang D, Niu L, Zhang M (2017) Evaluation of freeze drying combined with microwave vacuum drying for functional okra snacks: antioxidant properties, sensory quality, and energy consumption. LWT-Food Sci Technol 82(1):216-226. https://doi.org/10.1016/j.lwt.2017.04. 015

Juhaimi FA, Özcan MM, Uslu N, Ghafoor K (2018) The effect of drying temperatures on antioxidant activity, phenolic compounds, fatty acid composition and tocopherol contents in citrus seed and oils. J Food Sci Technol 55:190. https://doi.org/10. 1007/s13197-017-2895-y

Kwak AM, Lee IK, Lee SY, Yun BS, Kang HW (2016) Oxalic Acid from Lentinula edodes culture filtrate: antimicrobial activity on phytopathogenic bacteria and qualitative and quantitative analyses. Mycobiology 44(4):338. https://doi.org/10.5941/MYCO. 2016.44.4.338

Lang HG, Lindemann JS, Ferreira DC, Hoffmann JF, Vanier NL, de Oliveira M (2019) Effects of drying temperature and long-term storage conditions on black rice phenolic compounds. Food 
Chem 287:197-204. https://doi.org/10.1016/j.foodchem.2019. 02.028

Li H, Park S, Moon B, Yoo Y, Lee Y, Lee C (2012) Targeted phenolic analysis in Hericium erinaceum and its antioxidant activities. Food Sci Biotechnol 21:881-888. https://doi.org/10.1007/ s10068-012-0114-1

Li QZ, Wu D, Zhou S, Liu FY, Li ZP, Feng J, Yang Y (2016) Structure elucidation of a bioactive polysaccharide from fruiting bodies of Hericium erinaceus in different maturation stages. Carbohydr Polym 144:196-204. https://doi.org/10.1016/j.carb pol.2016.02.051

Liaotrakoon W, Liaotrakoon V (2018) Influence of drying process on total phenolics, antioxidative activity and selected physical properties of edible bolete (Phlebopus colossus (R. Heim) Singer) and changes during storage. Food Sci Technol 38(2):231-237. https://doi.org/10.1590/1678-457X.34116

Lin Q, Lu Y, Zhang J, Liu W, Guan W, Wang Z (2017) Effects of high $\mathrm{CO}_{2}$ in-package treatment on flavor, quality and antioxidant activity of button mushroom (Agaricus bisporus) during postharvest storage. Postharvest Biol Technol 123:112-118. https://doi. org/10.1016/j.postharvbio.2016.09.006

Lu QQ, Tian JM, Wei J, Gao JM (2014) Bioactive metabolites from the mycelia of the basidiomycete Hericium erinaceus. Nat Prod Res 28:1288-1292. https://doi.org/10.1080/14786419.2014. 898145

Maray AR, Mostafa MK, El-Fakhrany AED (2018) Effect of pretreatments and drying methods on physico-chemical, sensory characteristics and nutritional value of oyster mushroom. J Food Process Preserv 42(1):e13352. https://doi.org/10.1111/jfpp. 13352

Mattila P, Lampi AM, Ronkaine R, Toivob J, Piironen V (2002) Sterol and vitamin D2 contents in some wild and cultivated mushrooms. Food Chem 76:293-298. https://doi.org/10.1016/ S0308-8146(01)00275-8

Moro C, Palacios I, Lozano M, D’Arrigo M, Guillamón E, Villares A (2012) Anti-inflammatory activity of methanolic extracts from edible mushrooms in LPS activated RAW 264.7 macrophages. Food Chem 130:350-355. https://doi.org/10.1016/j.foodchem. 2011.07.049

Muenger K, Lerch K (1985) Copper metallothionein from the fungus Agaricus bisporus: chemical and spectroscopic properties. Biochemistry 24(24):6751-6756. https://doi.org/10.1021/ bi00345a004

Mutukwa IB, Hall CA III, Cihacek L, Lee CW (2019) Evaluation of drying method and pretreatment effects on the nutritional and antioxidant properties of oyster mushroom (Pleurotus ostreatus). J Food Process Preserv 43(4):e13910. https://doi.org/10.1111/ jfpp. 13910

Muyanja C, Kyambadde D, Namugumya B (2014) Effect of pretreatments and drying methods on chemical composition and sensory evaluation of oyster mushroom (Pluerotus oestreatus) powder and soup. J Food Process Preserv 38(1):457-465. https://doi.org/10.1111/j.1745-4549.2012.00794.x

Nowacka N, Nowak R, Drozd M, Olech M, Los R, Malmet A (2014) Analysis of phenolic constituents, antiradical and antimicrobial activity of edible mushrooms growing wild in Poland. LWTFood Sci Technol 59:689-694. https://doi.org/10.1016/j.lwt. 2014.05.041

Pendre NK, Nema PK, Sharma HP, Rathore SS, Kushwah SS (2012) Effect of drying temperature and slice size on quality of dried okra (Abelmoschus esculentus (L.) moench). J Food Sci Technol 49(3):378-381. https://doi.org/10.1007/s13197-011-0427-8

Perkowski J, Buśko M, Stuper K, Kostecki M, Matysiak A, Szwajkowska-Michałek L (2008) Concentration of ergosterol in small-grained contaminated and inoculated cereals. Biologia 63:542-547. https://doi.org/10.2478/s11756-008-0083-2
Phillips KM, Ruggio DM, Horst RL, Minor B, Simon RR, Feeney MJ, Haytowitz DB (2011) Vitamin D and sterol composition of 10 types of mushrooms from retail suppliers in the United States. J Agric Food Chem 59:7841-7853. https://doi.org/10.1021/ jf104246z

Priecina L, Karklina D, Kince T (2018) The impact of steamblanching and dehydration on phenolic, organic acidcomposition, and total carotenoids in celery roots. Innov Food Sci Emerg Technol 49:192-201. https://doi.org/10.1016/j.ifset.2018.01.008

Pu Y, Ding T, Wang W, Xiang Y, Ye X, Lie M, Liua D (2018) Effect of harvest, drying and storage on the bitterness, moisture, sugars, free amino acids and phenolic compounds of jujube fruit (Zizyphus jujuba cv. Junzao). J Sci Food Agric 98:628-634. https://doi.org/10.1002/jsfa.8507

Reid T, Merjury M, Takafira M (2017) Effect of cooking and preservation on nutritional and phytochemical composition of the mushroom Amanita zambian. Food Sci Nutr 5(3):538-544. https://doi.org/10.1002/fsn3.428

Ribeiro B, Rangel J, Valentão P, Baptista P, Seabra RM, Andrade PB (2006) Contents of carboxylic acids and two phenolics and antioxidant activity of dried Portuguese wild edible mushrooms. J Agric Food Chem 54:8530-8537. https://doi.org/10.1021/ jf061890q

Roncero-Ramos I, Mendiola-Lanao M, Pérez-Clavijo M, DelgadoAndrade C (2017) Effect of different cooking methods on nutritional value and antioxidant activity of cultivated mushrooms. Int J Food Sci Nutr 68(3):287-297. https://doi.org/10. 1080/09637486.2016.1244662

Ryvolova M, Krizkova S, Adam V, Beklova M, Trnkova L, Hubalek J, Kizek R (2011) Analytical methods for metallothionein detection. Curr Anal Chem 7:243-261. https://doi.org/10.2174/ 1573411011107030243

Sezer YC, Süfer Ö, Sezer G (2017) Extraction of phenolic compounds from oven and microwave dried mushrooms (Agaricus bisporus and Pleurotus ostreatus) by using methanol, ethanol and aceton as solvents. Indian J Pharm Educ 51(3s2):s393-s397. https://doi. org/10.5530/ijper.51.3s.55

Shao S, Hernandez M, Kramer JKG, Rinker DL, Tsao R (2010) Ergosterol profiles, fatty acid composition, and antioxidant activities of button mushrooms as affected by tissue part and developmental stage. J Agric Food Chem 58:11616-11625. https://doi.org/10.1021/jf102285b

Shukla Y, Singh M (2007) Cancer preventive properties of ginger: a brief review. Food Chem Toxicol 45(5):683-690. https://doi.org/ 10.1016/j.fct.2006.11.002

Sim KY, Liew JY, Ding XY, Chddng WS, Intan S (2017) Effect of vacuum and oven drying on the radical scavenging activity and nutritional contents of submerged fermented Maitake (Grifola frondosa) mycelia. Food Sci Technol 37(1):131-135. https://doi. org/10.1590/1678-457X.28816

Singleton VL, Rossi JA (1965) Colorimetry of total phenolics with phosphomolybdic-phosphotungstic acid reagents. Am J Enol Viticult 16:144-158

Slatnar A, Klancar U, Stampar F, Veberic R (2011) Effect of drying of figs (Ficus carica L.) on the contents of sugars, organic acids, and phenolic compounds. J Agric Food Chem 59:11696-11702. https://doi.org/10.1021/jf202707y

Sławińska A, Fornal E, Radzki W, Skrzypczak K, Zalewska-Korona M, Michalak-Majewska M, Parfieniuk E, Stachniuk A (2016) Study on vitamin D2 stability in dried mushrooms during drying and storage. Food Chem 199:203-209. https://doi.org/10.1016/j. foodchem.2015.11.131

Sommer I, Schwartz H, Solar S, Sontag G (2010) Effect of gammairradiation on flavour $5^{\prime}$-nucleotides, tyrosine, and phenylalanine in mushrooms (Agaricus bisporus). Food Chem 123(1):171-174. https://doi.org/10.1016/j.foodchem.2010.03.124 
Souilem F, Fernandes A, Calhelha RC, Barreira JCM, Barros L, Skhiri F, Martins A, Ferreira ICFR (2017) Wild mushrooms and their mycelia as sources of bioactive compounds: antioxidant, anti-inflammatory and cytotoxic properties. Food Chem 230:40-48. https://doi.org/10.1016/j.foodchem.2017.03.026

Stojković DS, Kovačević-Grujičić N, Reis FS, Davidović S, Barros L, Popović J, Pertrović I, Pavić A, Glamočlija J, Ćirić A, Stevanović M, Ferreira ICFR, Soković M (2017) Chemical composition of the mushroom Meripilus giganteus Karst. and bioactive properties of its methanolic extract. LWT-Food Sci Technol 79:454-462. https://doi.org/10.1016/j.lwt.2017.01.045

Sudheer S, Yeoh WK, Manickam S, Ali A (2016) Effect of ozone gas as an elicitor to enhance the bioactive compounds in Ganoderma lucidum. Postharvest Biol Technol 117:81-88. https://doi.org/10. 1016/j.postharvbio.2016.01.014

Sułkowska-Ziaja K, Muszyńska B, Motyl P, Pasko P, Ekiert H (2012) Phenolic compounds and antioxidant activity in some species of polyporoid mushrooms from Poland. Int J Med Mushrooms 14:385-393. https://doi.org/10.1615/IntJMedMushr.v14.i4.60

Šumić Z, Tepić A, Vidović S, Vakula A, Vladić J, Pavlić B (2017) Process optimization of chanterelle (Cantharellus cibarius) mushrooms vacuum drying. J Food Process Preserv 5(5):989-996. https://doi.org/10.1111/jfpp.12822

Toor RK, Savage GP (2006) Effect of semi-drying on the antioxidant components of tomatoes. Food Chem 94(1):90-97. https://doi. org/10.1016/j.foodchem.2004.10.054

Valentão P, Lopes G, Valente M, Barbosa P, Andrade PB, Silva BM, Baptista P, Seabra RM (2005) Quantification of nine organic acids in wild mushrooms. J Agric Food Chem 53:3626-3630
Vallespir F, Crescenzo L, Rodríguez Ó, Marra F, Simal S (2019) Intensification of low-temperature drying of mushroom by means of power ultrasound: effects on drying kinetics and quality parameters. Food Bioprocess Technol 12(5):839-851. https://doi.org/10.1007/s11947-019-02263-5

Villares A, Mateo-Vivaracho L, García-Lafuente A, Eva Guillamón E (2014) Storage temperature and UV-irradiation influence on the ergosterol content in edible mushrooms. Food Chem 147:252-256. https://doi.org/10.1016/j.foodchem.2013.09.144

Yang W, Du H, Mariga AM, Pei F, Ma N, Hu Q (2017) Hot air drying process promotes lignification of Lentinus edodes. LWT-Food Sci Technol 84:726-732. https://doi.org/10.1016/j.1wt.2017.06. 039

Yildiz O, Can Z, Laghari AO, Şahin H, Malkoç M (2015) Wild edible mushrooms as a natural source of phenolics and antioxidants. J Food Biochem 39(2):148-154. https://doi.org/10.1111/jfbc. 12107

Zhang S, Wang S, Shan X-q (2001) Effect of sample pretreatment upon the metal speciation in sediments by a sequential extraction procedure. Chem Spec Bioavailab 13(3):69-74. https://doi.org/ 10.3184/095422901782775435

Zhang Y, Mills GL, Nair MG (2002) Cyclooxygenase inhibitory and antioxidant compounds from the mycelia of the edible mushroom Grifola frondosa. J Agric Food Chem 50:7581-7585. https://doi.org/10.1021/jf0257648

Publisher's Note Springer Nature remains neutral with regard to jurisdictional claims in published maps and institutional affiliations. 